\title{
IMPLEMENTASI PROGRAM SANITASI TOTAL BERBASIS MASYARAKAT (STBM) UNTUK MENGURANGI KASUS STUNTING DI PUSKESMAS WILAYAH KABUPATEN SLEMAN
}

\author{
Merita Eka Rahmuniyati ${ }^{1}$, Sri Sahayati ${ }^{2}$ \\ Program Studi Kesehatan masyarakat Program Sarjana ${ }^{1,2}$ \\ Universitas Respati Yogyakarta ${ }^{1,2}$ \\ merita_er@ respati.ac.id ${ }^{1,}$, risafillah@gmail.com²
}

\begin{abstract}
Stunting is one of the malnutrition problems in Indonesia. Riskesdas 2018 shows that the prevalence of stunting in Sleman Regency is $11 \%$. Environmental sanitation problems and infectious diseases contribute to stunting cases. Efforts to reduce stunting can be done through sensitive nutrition interventions, namely by implementing the CBTS Program. This study aims to obtain an overview of the implementation of Community Based Total Sanitation to reduce stunting cases in the Community Health Center Sleman Regency. This study uses a qualitative research method with a case study approach. Data collection in August until November 2020 was carried out by in-depth interviews (indepth interviews) with informants. The validity of the data used source triangulation and qualitative data analysis used content analysis. The results of this study indicate that efforts to reduce stunting cases have been carried out through environmental factors, namely by implementing the five pillars of CBTS, namely stopping defecation, washing hands with soap, managing drinking water and household food, protecting household waste and protecting household liquid waste. The community has implemented the five pillars, but not all of them have been fulfilled. The efforts of the Primary Health Center in Sleman Regency are also very optimal in reducing stunting cases, namely by creating creative program innovation by combining the CBTS program with an accelerated stunting reduction program. The community has implemented the five pillars of CBTS in their daily lives, the implementation of the CBTS program is very useful in reducing stunting cases, improving personal sanitation and environmental hygiene and changing behavior to improve community health status.
\end{abstract}

Keywords $\quad$ : Implementation CBTS, Stunting

\begin{abstract}
ABSTRAK
Stunting merupakan salah satu permasalahan gizi kurang yang ada di Indonesia. Riskesdas 2018 menunjukkan bahwa prevalensi stunting di Kabupaten Sleman sebesar $11 \%$. Masalah sanitasi lingkungan dan penyakit infeksi memberikan kontribusi adanya kasus stunting. Upaya pengurangan stunting dapat dilakukan melalui intervensi gizi sensitif yakni dengan menerapkan Program STBM. Penelitian bertujuan untuk memperoleh gambaran implementasi STBM untuk mengurangi kasus stunting di Puskesmas Wilayah Kabupaten Sleman. Penelitian menggunakan metode penelitian kualitatif dengan pendekatan studi kasus. Pengumpulan data pada bulan Agustus - November 2020 dilakukan dengan wawancara secara mendalam (indepth interview) pada 20 informan. Keabsahan data meggunakan triangulasi sumber dan analisis data kualitatif menggunakan content analysis.Upaya menurunkan kasus stunting sudah dilakukan melalui faktor lingkungan yakni dengan melaksanakan lima pilar STBM yakni stop BABS, cuci tangan pakai sabun, pengelolaan air minum dan makanan rumah tangga, pengamanan sampah rumah tangga dan pengamanan limbah cair rumah tangga. Masyarakat sudah menerapkan lima pilar, namun memang belum semua pilar terpenuhi. Upaya pihak Puskesmas Wilayah Kabupaten Sleman juga sangat optimal untuk menurunkan kasus stunting dengan menciptakan kreativitas inovasi program dengan memadukan program STBM dengan program percepatan penurunan stunting sangatlah efektif. Masyarakat sudah menerapkan lima pilar STBM, implementasi program STBM bermanfaat menurunkan kasus stunting, meningkatkan hygiene personal sanitasi dan lingkungan serta perubahan perilaku untuk meningkatkan derajat kesehatan masyarakat.
\end{abstract}

Kata Kunci : Implementasi, STBM, Stunting 


\section{PENDAHULUAN}

Indonesia mempunyai masalah gizi yang cukup berat dengan ditandai banyaknya kasus gizi kurang. Stunting merupakan salah satu permasalahan gizi kurang yang di Indonesia. Stunting berhubungan dengan ketidakcukupan zat gizi masa lalu sehingga termasuk dalam masalah gizi yang bersifat kronis (Sutarto, Diana Mayasari, 2018). Berdasarkan Riset Kesehatan Dasar (Riskesdas, 2018) menunjukkan prevalensi balita stunting di Indonesia sebesar 30,8\%, sedangkan di Kabupaten Sleman 11,00\%.

Stunting pada anak merupakan dampak yang bersifat kronis. Masalah lingkungan dan penyakit infeksi memberikan kontribusi munculnya kasus stunting. Praktik hygiene yang buruk dapat menyebabkan balita terserang penyakit diare yang nantinya dapat menyebabkan anak kehilangan zat-zat gizi yang penting bagi pertumbuhan. Stunting disebabkan oleh faktor multidimensi dan tidak hanya disebabkan oleh faktor gizi buruk yang dialami oleh ibu hamil dan balita. Aspek personal hygiene dan sanitasi lingkungan mempunyai peran penting terhadap masalah kekurangan gizi termasuk stunting. Kebiasaan seperti buang air besar sembarangan dan rendahnya kebiasaan mencuci tangan tanpa sabun dapat meningkatkan kasus stunting serta meningkatkan frekuensi diare (Desyanti, Chamilia; Nindya, 2017).

Upaya pengurangan stunting dapat dilakukan melalui intervensi gizi spesifik dan intervensi gizi sensitif. Intervensi gizi sensitif idealnya dilakukan melalu berbagai kegiatan pembangunan di luar sektor kesehatan dan berkontribusi pada $70 \%$ intervensi stunting. Salah satu program yang dilaksanakan yakni Sanitasi Total Berbasis Masyarakat (STBM). Tujuan adanya Peraturan Menteri Kesehatan (Permenkes) RI Nomor 03 Tahun 2014 tentang STBM adalah untuk meningkatkan higienitas dan kualitas kehidupan masyarakat Indonesia. STBM merupakan pendekatan untuk mengubah perilaku higienis dan saniter melalui pemberdayaan masyarakat dengan cara pemicuan. STBM bertujuan untuk mewujudkan perilaku masyarakat yang higienis dan saniter secara mandiri dalam rangka meningkatkan derajat kesehatan masyarakat yang setinggi-tingginya (Kemenkes RI, 2017).

\section{METODE}

Penelitian ini menggunakan metode penelitian kualitatif dengan pendekatan studi kasus. Pengumpulan data dilakukan dengan wawancara secara mendalam (indepth interview) pada 20 informan pada Agustus - November 2020. Keabsahan data menggunakan triangulasi sumber dan analisis data kualitatif, meng gunakan content analysis. Analisis data diawali dengan transkrip dari hasil wawancara, kedua dilakukan reduksi data, ketiga melakukan koding data, berikutnya verifikasi dengan membuat kesimpulan dari hasil temuan penelitian. Penelitian ini telah melalui kelayakan etik dari komisi etik Universitas Respati Yogyakarta.

\section{HASIL}

\section{Program STBM}

\section{Desa Sudah Melaksanakan Deklarasi STBM}

Beberapa informan menyatakan bahwa seluruh desa di kabupaten Sleman sudah $100 \%$ melakukan Deklarasi STBM pilar 1 (Stop BABS). Stelah dilakukan Deklarasi tersebut selanjutnya akan menjadi Desa STBM namun diperlukan diperlukan upaya lebih optimal melalui pemetaan kemudian pemicuan ke dusun - dusun, kemudian verifikasi. Berikut kutipan informan terkait hal ini

“...sudah bu tahun yang lalu itu kami sudah ada deklarasi untuk deklarasi STBM nggeh ada beberapa sudah semua di situ melakukan deklarasi di puskesmas..." (Informan 8) 
“...oh...STBM ini program yang memang sudah lama berjalan nggeh Mbak sudah dari beberapa tahun yang lalu kita targetkan STBM itu untuk desa STBM itu memang 1 tahun itu satu desa nggih..." (Informan 16)

“...jadi untuk STBM ini tidak salah sudah mulai sejak tahun 2015 kalau enggak 2016 yaitu dan sudah mendeklarasikan STBM BABS di 2017 akhir itu November dan dari itu sudah setelah deklarasi kita membuka siapa yang berani mendeklarasikan kami persilahkan dengan syarat untuk yang pilar pertama itu kita harus verifikasi $100 \%$..." (Informan 19)

\section{Perubahan Perilaku Hygiene}

Informan menyatakan bahwa STBM lebih ke arah perubahan perilaku dalam hal sanitasi/perbaikan lingkungan secara individu dan pada awalnya mengajak atau melakukan suatu perubahan sangatlah sulit melakukan perubahan tersebut, tentunya membutuhkan waktu untuk dapat melakukan suatu perubahan. Berikut kutipan informan terkait hal tersebut :

“...kalau STBM sendiri itu prosesnya awal advokasi, advokasi dengan wilayah biasanya ke kecamatan istilahnya kulonuwun dulu mbak kecamatan, desa, tokoh masyarakat itu setelah melakukan advokasi lalu temanteman melakukan pemicuan nah pemicuan di masyarakat teman-teman sih sanitarian saya rasa cukup kreatif sampai dengan memicu untuk sampai membuat bank sampah memicu tidak buang air besar sembarangan terus terpicu juga karena pemicuan itu tantangannya banyak-banyak yang menyepelekan..." (Informan 19)

'...di dalam pemicuan itu kita biasanya lebih memprioritaskan mereka mempunyai perilaku mohon maaf istilahnya suka BAB situ harus diikutkan, suka buang sampah sembarangan di kebun di sungai itu harus digunakan agar terpicu nah salah satu pensiunan itu dia menyampaikan kalau seperti ini nggak bisa Mbak terpicu nggak mungkin program koyo ngene akhirnya dia ngeyel dalam pemicuan itu harus timbul namanya naturalizer nah dia itu harus apa ya istilahnya seseorang yang ditunjuk sebagai ketua atau koordinasikan untuk mengawal program itu harus terus berprogres akhirnya dia lah yang dijadikan sebagai natural leader dan juga tim fasilitator nah dari situ dia ditunjuk dan dia dipakai di luar wilayah diam, dipakai terus akhirnya dia merasakan oh iya Mbak dengan cara ini mereka bisa terpicu akhirnya pemicuan di masing-masing dusun setelah nanti pemicuan itu akan ada namanya verif aplikasi, verifikasi itu akan ada persiapan verifikasi verifikasi lapangan, verifikasi lapangan biasanya kadar yang nantinya akan mengawal itu dan juga didampingi orang-orang dari Puskesmas setelah itu pada saat verifikasi itu tetap akan didampingi dari pihak desa lalu Koramil biasanya juga ikut hasil verifikasi itu harus disampaikan pada saat pertemuan istilahnya monev hal-hal apa saja yang mereka temui di lapangan ada kendala apa saja yang mereka temui di lapangan halo teman-teman yang mungkin harus untuk segera diselesaikan disampaikan dari hasil verifikasi itu nanti biasanya direkap dalam dokumen verifikasi lalu staffnya mereka mengajukan pemicuan ke kami, jadi setiap awal tahun itu kami selalu ngelist desa desa mana saja yang melakukan deklarasi nggih setelah itu kami sudah ada listnya mereka mengajukan kami datang untuk verifikasi dokumen nya kami datang kembali nah setelah itu baru boleh deklarasi..." (Informan 19)

"...dari lima komponen di STBM itu eee ada tiga salah satunya adalah di perubahan perilaku yang kedua itu terkait dengan nanti aksesnya dan yang ke empat itu adalah eh mohon maaf yang ketiga itu nanti lebih keperan 
masyarakat, nah diliat dari tiga komponen itu yang menjadi tanggung jawab utama yang kesehatan adalah yang komponen yang pertama terkait perubahan perilaku karena memang benang merah dari STBM itu adalah bagaimana caranya kita untuk merubah perilaku karena merubah perilaku itu susah nggeh ketika kita belum merasakan efeknya, dampaknya itu pasti tidak mau untuk merubah seperti itu..." (Informan 19)

“...isinya ibu-ibu semua jadi yang bapak-bapak ngerjain teknisnya membuat instalasi seperti apa, ibunya nanti garap perubahan perilakunya di desa itu termasuk nanti gimana caranya stunting ini mungkin terus jadi terus STBM..."(Informan 19)

\section{Pilar dalam STBM}

a. Lima pilar STBM

Informan menyatakan bahwa pilar STBM terdiri dari lima pilar yakni (1) Stop Stop BABS, (2) Cuci tangan pakai sabun, (3) Pengelolaan air minum dan makanan rumah tangga, (4) Pengamanan sampah rumah tangga; dan (5) Pengamanan limbah cair rumah tangga. Namun ada juga informan lupa urutan ataupun pilar dari STBM. Informan menyatakan mengetahui bahwa STBM merupakan kebersihan lingkungan namun tidak mengingat terkait ada berapa pilar di dalam STBM walaupun sudah sering diingatkan oleh kader maupun petugas puskesmas. Berikut kutipan dari informan :

"..Saya tahunya ya tentang kebersihan Mba tapi nggak begitu paham si (tertawa). Kebersihan lingkungan tempat tinggal, biasanya yang sudah dilakukan itu buang air besar di jamban, cuci tangan, pengolahan air minum, pengelolaan sampah dan pengelolaan limbah..." (Informan 1)

“...Ada 5 pilar mbak, BAB di toilet, cuci tangan, pengolahan air minum dan makanan, sampah, limbah, itu kayaknya ya.." (Informan 7)

"...untuk program STBM di kabupaten Sleman ini sudah berjalan dengan baik dan STBM sendiri sudah tau nggeh kepanjangannya sanitasi berbasis masyarakat dimana dalam STBM itu terdapat 5 pilar. Pilar pertama adalah stop buang air besar sembarangan, pilar ke dua cuci tangan pakai sabun, pilar ke tiga pengelolaan makanan dan minuman rumah tangga, pilar ke empat pengamanan sampah rumah tangga, pilar ke lima adalah pengamanan limbah cair rumah tangga..." (Informan 19).

b. Implementasi STBM di masyarakat Stop Buang Air Besar Sembarangan (Stop BABS)

Informan menyatakan bahwa kebiasaan buang air besar sudah dilakukan di jamban yang ada di rumah masing - masing. Informan juga ada yang menyampaikan bahwa ada yang BAB di sungai namun itu hanya orang tua yang memiliki kebiasaan sulit BAB apabila tidak di sungai. Menurut informan hal ini dikarenakan BAB di sungai sudah menjadi kebiasaan melekat, sehingga membutuhkan waktu apabila akan mengubahnya. Berikut kutipan informan terkait stop BABS :

“...STBM nya terutama yang ini $B A B$ itu yang di pinggir kali itu memang sudah punya jamban tapi mereka masih menggunakan sungai karena mereka belum terbiasa, jadi belum terbiasa untuk BAB di jamban sehat. Untuk empat pilar lainnya saya kira yang mereka sudah menerapkan itupun kalau untuk yang saluran pembuangan air limbahnya itu kadang ada juga yang belum punya untuk SPAL nya..." (Informan 7) 
1) Cuci tangan pakai sabun

Informan menyatakan bahwa ada cuci tangan pakai sabun sudah merupakan pembiasaan yang ada di masyarakat (sebelum pandemi) sudah melekat ada dimasyarakat.

Berikut kutipan informan terkait CPTS :

"...iya itu tadi kehidupan seharihari itu Mbak kayak cuci tangan, airnya harus bersih terus limbahlimbah gitulah, itu nanti akan menyebabkan ini ya apa ya menyebabkan jika pengelolaan tidak benar bisa menimbulkan suatu penyakit gitu ya Bu ya kena penyakit itu yang bisa mengarahkan ke balita yang sakit nggeh..." (Informan 4)

“...untuk cuci tangan itu kalau kemarin sudah membudidaya sih Mbak cuci tangan jadi kita di setiap rumah itu ada kebetulan kemarin itu juga habis lomba si Mbak lomba yang PKK, jadi mulai dari itu cuci tangan udah berjalan baik..." (Informan 9)

2) Mengelola air minum dan makanan rumah tangga

Informan menyatakan bahwa air minum dan makanan yang tercemar akan menyebabkan diare, terutama pada anak - anak. Air yang digunakan mengguanakan air sumur untuk keperluan sehari - hari, namun untuk air minum menggunakan air kemasan. Namun ada juga informan yang menyampaikan penggunaan air minum menggunakan air rebusan yang berasal dari sumur. Berikut kutipan informan terkait pilar ke-3 :

“...untuk pengelolaan air minum Alhamdulillah kita sudah menggunakan air minum yang baik yang harus diolah dulu tidak mentah terus juga airnya air yang bagus yang kriterianya tidak berwarna tidak berasa tidak berbau itu Alhamdulillah sudah airnya sudah bersih semua..." (Informan 11)

“...pedagang somay karena itu kan juga masuk pilar 3 ya pilar ketiga jadi kita, kita ada tapi kita kan nggak mungkin kita bina nya hampir kurang lebih enam puluhan pedagang ini kan nggak mungkin kita datangi satu-satu yang saya bilang itu yang mereka berjualan nya di wilayah Puskesmas Godean, walaupun rumahnya ada yang ngekos di tempel ada kos di Sedayu Bantul tapi mereka berjalannya di wilayah sini jadinya yang saya datangi biasanya pedagang yang jualannya wilayah Puskesmas Godean, nah itu cuman sampling saja oh kondisi cara pengolahannya seperti ini tetapi kalian dari luar biasanya saya inspeksi nya biasanya barengan istilahnya di lokasi mereka jualan jadi siswa masuk biasanya kita tanya kondisi, saya lihat kukunya lihat terus saus sambelnya dan sebagainya yang alat makannya yang di buat ngambil dana lainnya nah kita lihat di situ misal kukukukunya kok masih panjang kita tegur biasanya nggeb karena kalau mereka tidak patuh stiker kita tarik nggeh..." (Informan 18)

3) Mengamankan sampah rumah tangga

Informan menyampaikan bahwa sampah rumah tangga dibakar di pekarangan rumah, terutama sampah dari plastik dan untuk sampah sisa makanan diberikan ke ayam maupun hewan ternak atauapun juga ada yang di jadikan pupuk tanaman. Selain itu, sampah ada juga yang membuang tersebut di sungai (terutaama mayarakat yang letaknya di atas), sehingga sampah - sampah tersebut akan turun ke bawah terbawa arus 
sungai, akhirnya akan mencemari sungai. Namun, seiring berjalannya waktu, sehingga warga memiliki inisiatif untuk buang sampah di TPS, sampah dikolektifkan. kemudian diambil pengepul sampah. Berikut kutipan informan terkait sampah rumah tangga :

“...itu yang plastik plastik itu banyak yang dibakar, ya terus kalau yang sisa makanan basah itu, dijadikan pupuk, ditaruh di bak ember itu caranya dikasih kan..." (Informan 6)

"...terus untuk urusan sampah, urusan sampah di awal-awal sungai kotor sering membuang sampah di sungai sekarang sudah ada intinya ada pemilahan Mbak pemilahan tapi juga nggak $100 \%$ warga dipilah-pilah itu terus apa lagi cuci tangan ya..." (Informan 9)

“...terus untuk pengelolaan sampah kita juga alhamdulillah kita sudah ada pemilahan sampah yang kalau bisa dijual kita jual terus uangnya dimasukkan di kas desa misal RT RW baik dusun itu kesepakatan masing-masing wilayah terus untuk yang sampah tidak bisa dijual itu di genitem juga sudah ada beberapa rumah atau bahkan ada satu RT sudah ada pengambilan dari bank sampah itu yang jemput yang pengepul itu bayar setiap bulannya Rp 30.000 untuk sampah yang tidak bisa dijual..." (Informan 11)

4) Mengamankan limbah cair rumah tangga

Informan menyampaikan untuk limbah cair rumah tangga limbah ini biasanya langsung dialirkan $\mathrm{k}$ sungai, namun ada juga yang memiliki penampungan sendiri. Masyarakat ada yang memiliki bak penampung limbah cair rumah tangga sebagai penyaring limbah sebelum dialirkan ke sungai. Berikut ini kutipan informan :

“...terus untuk pengelolaan limbah kita untuk pengelolaan limbah rumah tangga Alhamdulillah di dusun sudah sadar karena limbah itu pencemaran sudah banyak yang apa tidak membuang limbahnya dari kali atau di tanah lapang..." (Informan 11)

“...udah pernah ada sosialisasi juga soalnya kan di tempat saya di karena kidul itu dekat sungai kan Mbak masih banyak yang pada mekong mekong itu loh buang air besar di sungai itu tersosialisasi nya kan tentang itu terus yang mas Endi yang pernah ke sini tuh tentang pengolahan limbah cair itu ya Mbak kan masih banyak juga yang belum punya septitank itu lho mbak nah terus itu didata diajukan juga supaya dapat bantuan itu dia pernah kita cuma sosialisasi sosialisasi itu terus itu pelatihan pengelolaan sampah rumah tangga itu udah pernah daur ulang sampah gitu..." (Informan 12)

\section{Pemahaman penyebab stunting}

1. Penyebab stunting

Penyebab dari stunting adalah rendahnya asupan gizi pada $1.000 \mathrm{HPK}$, yakni sejak janin hingga bayi umur dua tahun (Pusdatin, 2018). Beberapa informan berpendapat bahwa stunting dapat terjadi karena kurang gizi, tidak asi eksklusif, pemberian makan yang kurang, ibu anemia, BBLR. Berikut kutipan informan :

"...stunting itu kekurangan berat badan anaknya kecil, penyebabnya kekurangan gizi, sewaktu apa kayak asi juga mempengaruhi..." (Informan 4)

“...stunting itu penyebabnya saya kira itu bisa jadi karena bayi waktu 
lahir itu berat badannya kurang, kemungkinan juga bisa ASI eksklusif nya tidak terpenuhi kemudian juga pemberian makan nya kurang..."(Informan 8)

2. Anggapan stunting karena keturunan

Ada seorang informan bercerita bahwa anaknya termasuk anak kurang gizi, namun informan terkesan belum menerima apabila anaknya dikatakan kurang gizi/stunting, karena anaknya termasuk anak yang aktif dan menganggap bahwa anaknya kecil karena ayah dan ibu balita memang pendek, sehingga anaknya mengalami pertumbuhan pendek (faktor keturunan). Berikut kutipan informan :

"...sangat bisa, lingkungan juga bisa. Anak saya dikatakan kurang gizi, padahal itu karena bisa jadi tinggi badannya tidak sesuai karena keturunan.." (Informan 3)

3. Lingkungan dan penyakit infeksi sebagai penyumbang terjadinya stunting

Informan menyampaikan bahwa penyebab stunting tidak hanya berasal dari asupan makanan, ibu dengan riwayat anemia, BBLR, namun juga dikarenakan faktor lain seperti lingkungan yang kotor, perilaku tidak sehat lainnya seperti BABS. Perilaku yang tidak tersebut dapat menyebabkan penyakit infeksi seperti diare. Berikut kutipan informan :

"..Sangat berkontribusi karena kalau misal makanannya itu banyak tapi lingkungannya tidak bagus kesananya gampang sakit kan ya udah otomatis makanannya untuk melawan sakitnya aja tidak ada yang untuk tumbuh, oleh karena itu dari sisi lingkungan harus diperbaiki juga gitu nggeh dan bahkan misalnya saya punya kasus gizi buruk untuk kunjungan rumah juga melibatkan bagian kesling karena bisa jadi pernah ada kasus gizi buruk lantainya masih tanah ada burungnya cemantel di dalam nah kita kan nggak bisa kasih edukasinya jadi kita mengajak dari yang lain..." (Informan 13)

“...lingkungan itu kalau lingkungan yang bersih anak jadi saya temannya kalau kurang bersih bisa menyebabkan anak sakit-sakitan terus anak sakitsakitan itu kan di pertumbuhannya terganggu asupan gizi orang jadi pertumbuhannya terganggu..." (Informan 8)

Informan berpendapat bahwa penyakit infeksi seperti diare atau ISPA dapat menyebabkan stunting pada balita. Berikut kutipan informan

“...iya jelas berkaitan mba, kalau balita mengalami diare, banyak energi yang hilang untuk penyembuhan, nafsu makan menurun. Diare terjadi karena lingkungan yang kotor..." (Informan 2)

"...kalau menurut saya ada Mbak karena infeksi yang terus-menerus berulang-ulang dengan asupan gizi yang kurang untuk stunting ini ya jelas mempengaruhi karena itu masa lampautidak hanya saat ini toh jadi memang lingkungan itu paling tidak harus dibenahi nggih, jadi kaitannya erat untuk lingkungan..." (Informan 14)

“...ada kan memang ada dua ya asupan makan sama dari faktor penyakit penyerta. Faktor penyakit penyerta juga mempengaruhi karena di sini juga banyak sih yang anak-anak diare kemudian ISPA itu juga lumayan kunjungan di Puskesmas sih lumayan bisa kalau di anak-anak itu nomor 4 terbanyak kasus ISPA..." (Informan 15)

\section{Implementasi Program STBM untuk Menurunkan Kasus Stunting}

Berdasarkan hasil interview dari beberapa informan bahwa program STBM ini sangat bermanfaat terhadap kebersihan lingkungan, perubahan perilaku untuk meningkatkan derajat kesehatan sekaligus menurunkan kasus stunting. Berikut kutipan informan : 
“...dari 5 pilar STBM yang sudah jalan pilar stop BAB sembarangan, cuci tangan pakai sabun, pengelolaan makan ya sudah rata-rata sudah bagus tapi kandang ternak masuk apa ya, tapi sampai sekarang kan ada pengelolaan sampah udah mending.." (Informan 10)

"...iya itu kita baru mulai di tahun kemarin 2019 karena kebetulan 2019 itu kita stuntingnya sebenarnya sudah turun trennya dari 2016 itu kita sudah selalu turun tapi masih kalau di kabupaten Sleman itu tahun kemarin kita masih rangking 2 jadi kita mau cari keluhannya dari asupan saja atau mungkin ada faktor pemberatnya ternyata memang bisa jadi ada kaitannya kenapa anak diare karena kualitas airnya tidak bersih, terus juga kebetulan di tahun kemarin itu yang paling tinggi kita di desa candibinangun itu ada beberapa kantong kantong dusun yang memang tinggi nah di situ biasanya dilihat dari hasil PIS-PK itu perilaku buang air besar sembarangan masih ada padahal sebetulnya di situ sudah STBM nya cuman kadang-kadang masyarakat itu terutama mungkin bukan yang mudamuda justru simbah-simbah itu, iya agak sulit karena mungkin kebiasaan dari lama nggeh" (Informan 13).

"...nah lima pilar itu kalau tidak diterapkan sesuai dengan yang benar atau tidak sesuai standar itu kan bisa mempengaruhi berbagai macam hal terutama penyakit yang berbasis lingkungan dan kalau untuk anak balita termasuk tumbuh kembang itu, karena tumbuh kembang itu sangat berpengaruh misalnya dengan penyakit diare yang gampang itu biasanya kita tekan kan di situlah diare itu berkaitan dengan 5 pilar itu tidak baik perilaku buang air besar larangan perilaku cuci tangan pakai sabun pengelolaan makanan, pengelolaan sampah dan limbah rumah tangga itu kan menyebabkan penyakit berbasis lingkungan yang pertama diare. Nah diare itu berkaitan dengan kejadian pada balita bayi itu berkaitan dengan tumbuh kembangnya menyebabkan bisa stunting anak.." (Informan 16)

"...kalau selama ini beberapa hal pernah lakukan sampai sejauh itu antara stunting dengan perilaku di STBM kemarin intervensinya untuk pengentasan stunting kita masih pada anu penekanannya pada air bersih, iya itu kita mulai sudah melakukan pemeriksaan air kualitas air, pada kantong kantong stunting. Setelah ini dilakukan sesudah karena untuk pemeriksaan stunting untuk pemeriksaan kualitas air di kantong stunting itu sejak tahun lalu 2019 itu meskipun hanya yang diperiksa hanya bakteri karena kalau diare kemungkinan bisa disebabkan oleh air, air di sini pilar pilar STBM itu kalau air tidak sehat bisa tidak memenuhi 5 pilar STBM. Apabila tidak memenuhi 5 pilar STBM dari yang disyaratkan pencemaran terhadap air kan cukup tinggi yaitu biasanya kita yang kita kita itu baru dikerucutkan itu baru kualitas airnya..." (Informan 16)

Beberapa informan menyampaikan bahwa pada tahun 2019 Pemerintah Kabupaten Sleman telah membentuk Tim Percepatan Penanggulangan Balita Stunting Kabupaten Sleman Berikut kutipan dari informan .

“...Program kita untuk penurunan stunting itu kebetulan dari mulai tahun 2019 itu sudah terbit peraturan Bupati No 27 tentang percepatan penanggulangan balita stunting itu isinya ada beberapa inovasi yang tercantum di dalamnya itu eee ada pandu teman, getar tala, ada pecah ranting, ada gambang stunting dan yang terakhir ada TOS HIV itu ada 5 yang tercantum di dalam peraturan Bupati tersebut tapi 4 yang mengarah ke stunting itu program inovasi di bidang kesehatan..." (Informan 20)

\section{Inovasi Program STBM untuk Menurunkan Kasus Stunting}

Selain program tersebut, informan juga menyampaikan terkait upaya penanggulangan stunting dengan inovasi program STBM yang merupakan kreasi 
inovasi masing - masing puskesmas. Puskesmas Pakem memiliki inovasi pemeriksaan air minum pada kantong kantong stunting dan GAYA PUSPAKU dengan salah satu kegiatannya melakukan sosialisasi IMD, asi ekslusif, MP-ASI, sanitasi, PHBS pada pertemuan bapakbapak. Puskemas Tempel II membuka klinik sanitasi bagi ibu hamil, dan bimbingan 1000 HPK (intervensi program gizi dan kesling) serta pemeriksaan air bersih/minum pada kantong - kantong stunting, kemudian Puskesmas Godean I mengadakan IPAL komunal untuk warga dan membuat komunitas pedagang cilok untuk diberikan bimbingan terkait pengelolaan/pengamanan air minum dan makanan. Berikut kutipan informan :

“...gaya puspaku, gerakan ayah peduli seribu hari pertama kehidupan (nama brandnya)..." (Informan 13)

“...kalau lingkungannya nggak sehat kemungkinan saya akhirnya buka ini tho mbak sudah berapa tahun ya saya buka klinik sanitasi untuk menanggulangi salah satunya stunting saya buka klinik sanitasi jadinya orang yang hamil masuk ke masuk klinik sanitasi, banyak koo perbulannya kadang yo 30 kadang 25 kan gitu tetap ada, setiap orang hamil harus kunjungi minimal sekali..." (Informan 17)

“... iya saya lebih menekankan pada PHBS, misalnya ini sekarang PHBS kan ada 12 ini untuk ini kan perilaku nya ini membiasakan cuci tangan, kalau ini kan ini orang kesling to harus menggunakan jamban, air bersih, rumah bebas jentik, tambah 2 lagi kan sekarang pengelolaan limbah cair sama sampah, PHBS kan ada tambah 12. Sekarang indikator ini kan orang hamil, orang hamil itu kan sehat kalau lingkungannya sehat kalau lingkungannya nggak sehat orang hamil itu hasil nya juga bisa stunting juga, percaya nggak percaya mboten, misale omahe kumuh iso turun karena orang hamil itu butuh istirahat yang nyaman 8 jam minimal, ndilalahe omahe reget ting klarah ting klrumbuk opo yo turune nyaman pengap lagi kalau, kalau sanitasinya jelek nah nafsu makan umpane lingkungannya reget nggo makan we wegah nah makanya ada disitu lek wegah terus hasil bayine tidak berkembang dengan maksimal kalau nggak maksimal kemungkinan bisa terjadi stunting gizi buruk kan gitu.." (Informan 17)

“...kami ada pertemuan rutin di puskesmas setiap awal tiap akhir bulan maaf tiap akhir bulan hingga disitu kami bisa berkoordinasi dan karna tahun 2017 itu puskesmas Godean 1 kan kasusnya tertinggi stuntingnya sehingga kami gencar eee untuk menanggulangi itu dengan berbagai anggaran bahkan di kecamatan di desa di puskesmas seтua dikerahkan untuk mengatasi stunting itu yang Alhamdulillah tahun 2019 itu kemarin sudah turun jadi rangking 4 walaupun masih 5 besar tapi ya kan itu prosesnya kan panjang, kalau kader sendiri sudah melakukan sosialisasi pelatihan-pelatihan pemberian makanan bayi dan anak eee kemudian ada pelatihan motivator ASI itu yang dalam rangka mendukung itu..." (Informan 15)

“...IPAL Komunal ini memang apa ya sangat membantu kaitannya dengan pilar kelima dan juga bila ketiga karena memang di pilar ketiga yaitu menggunakan air bersih itu memang kondisi air bersih di wilayah Puskesmas Godean 1 ini hampir $75 \%$ itu sudah tercemar ecoli, maksudnya ecoli sudah melebihi ambang batas nah kemungkinan untuk padukuhan padukuhan yang sudah ada IPAL Komunal nya ini memang sangat membantu sekali dikarenakan (suara pemanggilan pasien) kualitas air bersih nya sedikit lumayan baik, sedikit lumayan baik karena semua saluran disalurkan ke IPAL Komunal jadinya kualitas air bersihnya sekarang jadi lebih baik.." (Informan 18)

\section{Inovasi Program STBM untuk Menurunkan Kasus Stunting}

Selain program tersebut, informan juga menyampaikan terkait upaya 
penanggulangan stunting dengan inovasi program STBM yang merupakan kreasi inovasi masing - masing puskesmas. Puskesmas Pakem memiliki inovasi pemeriksaan air minum pada kantong kantong stunting dan GAYA PUSPAKU dengan salah satu kegiatannya melakukan sosialisasi IMD, asi ekslusif, MP-ASI, sanitasi, PHBS pada pertemuan bapakbapak. Puskemas Tempel II membuka klinik sanitasi bagi ibu hamil, dan bimbingan 1000 HPK (intervensi program gizi dan kesling) serta pemeriksaan air bersih/minum pada kantong - kantong stunting, kemudian Puskesmas Godean I mengadakan IPAL komunal untuk warga dan membuat komunitas pedagang cilok untuk diberikan bimbingan terkait pengelolaan/pengamanan air minum dan makanan.

\section{PEMBAHASAN}

\section{Program STBM}

Upaya pengurangan stunting dapat dilakukan melalui intervensi gizi sensitif. Intervensi gizi sensitif berkontribusi pada $70 \%$ intervensi stunting. Salah satu program yang dilaksanakan yakni STBM. STBM adalah untuk meningkatkan higienitas dan kualitas kehidupan masyarakat Indonesia. Saat ini STBM bukan hanya sekedar suatu upaya pemberdayaan masyarakat yang terkait air dan sanitasi saja, begitu juga dengan stunting bukan hanya karena kurang konsumsi,

maka STBM dikembangkan sebagai upaya pemberdayaan masyarakat dalam rangka penanganan stunting yang dikenal sebagai STBM Stunting.

Desa yang telah mendeklarasikan Stop BABS sudah mencapai 86 desa (100\%) dan sudah deklarasi kabupaten stop BABS pada tanggal 9 nopember 2017 berdasarkan Surat Keputusan Bupati Sleman nomor 124/Kep.KDH/A/2017 tentang Deklarasi stop BABS Kabupaten Sleman. Selanjutnya pasca deklarasi stop BABS sebagian desa dipicu untuk menjadi desa STBM dan sampai dengan tahun 2018 sudah ada 61 desa yang deklarasi desa STBM (Dinas Kesehatan Kabupaten Sleman, 2020).

\section{Perubahan Perilaku Hygiene}

STBM adalah pendekatan untuk mengubah perilaku higienis dan saniter melalui pemberdayaan masyarakat dengan cara pemicuan. STBM diatur dalam Peraturan Menteri Kesehatan No.3 Tahun 2014 tentang Sanitasi Total Berbasis Masyarakat. STBM bertujuan untuk mewujudkan perilaku masyarakat yang higienis dan saniter secara mandiri dalam rangka meningkatkan derajat kesehatan masyarakat yang setinggi-tingginya (Kemenkes RI, 2014).

\section{Implementasi lima pilar STBM}

Lima pilar STBM terdiri dari lima pilar yakni

\section{(1) Stop Stop BABS}

Hasil penelitian menunjukkan informan menyampaikan masih ada kebiasaan buang air besar sudah dilakukan di jamban yang ada di rumah masing - masing. Informan juga ada yang menyampaikan bahwa ada yang $\mathrm{BAB}$ di sungai namun itu hanya orang tua yang memiliki kebiasaan sulit BAB apabila tidak di sungai. Menurut informan hal ini dikarenakan $\mathrm{BAB}$ di sungai sudah menjadi kebiasaan melekat, sehingga membutuhkan waktu apabila akan mengubahnya. Hal ini sesuai dengan penelitian yang dilakukan oleh Indriyani, dkk (2016) menunjukkan bahwa peningkatan perubahan perilaku masyarakat untuk Stop BAB secara sembarangan di Kelurahan Tirto, namun belum 100\% ODF (Indriyani, Yuniarti and Nur Latif, 2016).

(2) Cuci tangan pakai sabun Hasil penelitian menunjukkan bahwa ada cuci tangan pakai sabun sudah merupakan pembiasaan yang ada di masyarakat (sebelum pandemi) sudah 
melekat ada dimasyarakat. Cuci tangan pakai sabun (CPTS) dapat menjaga hygiene sanitasi individu dan terhindar dari penyakit. Informan juga menyampaikan bahawa dari pilar STBM yang sudah diterapkan adalah pilar yang kedua ini. Masing - masing rumah, tempat umum dan tempat lainnya telah disediakan tempat cuci tangan. Sosialisasi langkah - langkah CPTS ini juga sudah dilakukan saat posyandu, PKK, pertemuan warga tingkah dusun sampai desa. Hal ini sejalan dengan penelitian yang dilakukan oleh Indriyani, dkk (2016) bahwa sudah ada komitmen masyarakat untuk andil dalam membudayakan perilaku CTPS ini. Fasilitator STBM telah membantu untuk mendukung pilar tersebut melalui penyelenggaraan pengadaan sarana tempat cuci tangan. Sosialisasi langkah-langkah CTPS sering dilaksanakan pada pertemuanpertemuan seperti pertemuan pihak sekolah dengan wali murid, PKK, posyandu (Indriyani, Yuniarti and Nur Latif, 2016). Kebiasaan yang berhubungan dengan kebersihan perorangan yang penting dalam penularan kuman diare adalah mencuci tangan. Mencuci tangan dengan sabun, terutama sesudah buang air besar, sesudah membuang tinja anak dan sebelum makan, menurunkan angka kejadian diare sebesar 47\% (Kemenkes RI, 2011).

(3) Pengelolaan air minum dan makanan rumah tangga

Informan menggunakan air sumur dalam keperluan sehari - hari seperti memasak, mencuci baju, piring, membersihkan rumah, sedangkan untuk minum, menggunakan air yang sudah direbus. Menurut Proverawati and Rahmawati (2012) menyatakan air yang digunakan sebagai air minum harus aman dan memenuhi berbagai syarat kesehatan. air minum yang baik harus memenuhi persyaratan fisik, syarat bakteriologis dan syarat kimia. Persyaratan fisik yang digunakan sebagai standar untuk menentukan air minum yang sehat adalah tidak berwarna, tidak berasa, tidak berbau dan suhunya berada di bawah suhu lingkungan sekitarnya. Secara bakteriologis, air minum yang sehat harus bebas dari segala bakteri, terutama bakteri-bakteri yang memiliki sifat pathogen dan berbahaya bagi peminumnya. Informan menyatakan bahwa air minum dan makanan yang tercemar akan menyebabkan diare, terutama pada anak - anak. Penelitian yang dilakukan oleh Wandansari (2014) menunjukkan hubungan antara kualitas sumber air minum $(\mathrm{p}=0,008)$ dan pemanfaatan jamban keluarga $(\mathrm{p}=$ 0,005) dengan kejadian diare.

(4) Pengamanan sampah rumah tangga

Informan menyampaikan bahwa sampah rumah tangga dibakar di pekarangan rumah, sampah sisa makanan diberikan ke ayam maupun hewan ternak, dan dijadikan pupuk tanaman. Adapula yang menyatakan membuang sampah di sungai. Namun, seiring berjalannya waktu, sehingga warga memiliki inisiatif untuk buang sampah pada tempatnya. Permasalahan sampah rumah tangga telah menjadi budaya masyarakat. Perilaku buang sampah di sungai maupun dibakar, dikarenakan masyarakat ada yang merasa lebih simple dengan dibakar mengingat memiliki lahan luas di belakang rumah dan memilih membuang sampai di sungai juga adaya retribusi dan belum ada fasilitas yang tersedia. Menurut Nyakaana (1997) dibutuhkan komitmen masyarakat dalam penanganan sampah harus diimbangi dengan penyediaan fasilitas sanitasi yang memadai.

(5) Pengamanan limbah cair rumah tangga.

Berdasarkan hasil penelitian, untuk limbah cair rumah tangga limbah ini biasanya langsung dialirkan ke sungai, 
namun ada juga yang memiliki penampungan sendiri. Masyarakat ada yang memiliki bak penampung limbah cair rumah tangga sebagai penyaring limbah sebelum dialirkan ke sungai. Menurut penelitian yang dilakukan Indriyani, dkk tahun 2016 menyatakan bahwa sungai menjadi muara pembuangan limbah cair rumah tangga dari warga. Muara limbah tersebut berasal dari Kabupaten Pekalongan. Tentu saja kondisi ini membuat air sungai menjadi tercemar (Indriyani, Yuniarti and Nur Latif, 2016).

\section{Stunting}

\section{Pemahaman penyebab stunting}

Status gizi anak dengan pendek (stunting) dan sangat pendek (severe stunting) didasarkan pada indeks panjang badan menurut umur $(\mathrm{PB} / \mathrm{U})$ atau tinggi badan menurut umur (TB/U). Stunting (tubuh pendek) merupakan keadaan tubuh yang pendek dan sangat pendek sehingga melampaui defisit -2 SD dibawah median panjang atau tinggi badan (Kementerian Kesehatan Republik Indonesia, 2018). Berdasarkan Riset Kesehatan Dasar (Riskesdas, 2018) menunjukkan balita stunting dan kurus masih tinggi di Indonesia yaitu balita stunting sebanyak $30,8 \%$, sedangkan di Kabupaten Sleman tahun 2018 menunjukkan prevalensi balita stunting 11,00\% (Dinas Kesehatan Kabupaten Sleman, 2018). Berdasarkan Profil Kesehatan Kabupaten Sleman Tahun 2019 menunjukkan bahwa prevalensi balita stunting Kabupaten Sleman mengalami penurunan yakni sebesar 8,38\% (Dinas Kesehatan Kabupaten Sleman, 2020).

Penyebab dari stunting adalah rendahnya asupan gizi pada $1.000 \mathrm{HPK}$, yakni sejak janin hingga bayi umur dua tahun (Pusdatin, 2018). Beberapa informan berpendapat bahwa stunting dapat terjadi karena kurang gizi, tidak asi eksklusif, pemberian makan yang kurang, ibu anemia, BBLR. Seorang informan menyatakan anaknya termasuk anak kurang gizi, namun informan terkesan belum menerima apabila anaknya dikatakan kurang gizi/stunting, karena anaknya termasuk anak yang aktif dan menganggap bahwa anaknya kecil karena ayah dan ibu balita memang pendek, sehingga anaknya mengalami pertumbuhan pendek (faktor keturunan). Pendapat senada juga dikemukakan oleh Black and Krishnakumar (1999) menyatakan anak dari keluarga yang tinggi akan memiliki tinggi badan yang lebih tinggi saat lahir dan akan meningkat lebih cepat sejalan dengan waktu (Black and Krishnakumar, 1999). Penelitian dari Esfarjani et al. (2013) juga menunjukkan kejadian stunting berhubungan kuat dengan faktor berat badan kelahiran, usia ibu, dan tinggi badan ayah (Esfarjani et al., 2013).

Informan menyampaikan bahwa penyebab stunting tidak hanya berasal dari asupan makanan, ibu dengan riwayat anemia, BBLR, namun juga dikarenakan faktor lain seperti lingkungan yang kotor, perilaku tidak sehat lainnya seperti BABS. Perilaku yang tidak tersebut dapat menyebabkan penyakit infeksi seperti diare. Hal ini sejalan penelitian yang dilakukan oleh Sandra, dkk (2017) menyatakan bahwa kebiasaan seperti buang air besar sembarangan dan rendahnya kebiasaan mencuci tangan tanpa sabun dapat meningkatkan kasus stunting serta meningkatkan frekuensi diare (Sandra, Syafiq and Veratamala, 2017). Selain rendahnya asupan gizi pada 1.000 HPK, terdapat faktor lain penyebab terjadinya stunting yakni buruknya fasilitas sanitasi, minimnya akses air bersih, dan kurangnya kebersihan lingkungan juga menjadi penyebab stunting. Kondisi kebersihan yang kurang terjaga membuat tubuh harus secara ekstra melawan sumber penyakit sehingga menghambat penyerapan gizi (Pusdatin, 2018). Masalah lingkungan dan penyakit infeksi memberikan kontribusi munculnya kasus stunting. Praktik hygiene yang buruk dapat menyebabkan balita terserang penyakit diare yang nantinya dapat menyebabkan anak kehilangan zatzat gizi yang penting bagi pertumbuhan. Stunting disebabkan oleh faktor 
multidimensi dan tidak hanya disebabkan oleh faktor gizi buruk yang dialami oleh ibu hamil dan balita. Aspek personal hygiene dan sanitasi lingkungan mempunyai peran penting terhadap masalah kekurangan gizi termasuk stunting. Sanitasi berhubungan dengan kesehatan lingkungan yang mempengaruhi derajat kesehatan masyarakat. Buruknya kondisi sanitasi akan berdampak negatif di banyak aspek kehidupan, mulai dari turunnya kualitas lingkungan hidup masyarakat, tercemarnya sumber air minum bagi masyarakat, dan munculnya beberapa penyakit (Kemenkes RI, 2016).

\section{Implementasi Program STBM untuk Menurunkan Kasus Stunting}

Sejak tahun 2018 hingga sekarang, Kabupaten Sleman sudah melaksanakan STBM, ditandai dengan adaya Deklarasi yang sudah terlaksana, hingga mendapatkan penghargaan STBM AWARD pada tahun 2020 ini. Hal ini ternyata juga senada dengan adanya penurunan kasus stunting di Kabupaten Sleman. Berdasarkan hasil Riskesdas 2018, prevalensi stunting sebesar $11 \%$ (Kemenkes RI, 2018), namun pada tahun 2019 prevalensi stunting turun menjadi $8,38 \%$. Turunnya prevalensi stunting di Kabupaten Sleman ini dikarenakan adanya upaya penerapan program STBM yang sudah optimal di tingkat masyarakat.

Upaya menurunkan kasus stunting sudah dilakukan melalui faktor lingkungan dengan melaksanakan lima pilar STBM. Lima pilar yakni pilar STBM terdiri dari lima pilar yakni Stop Stop BABS, Cuci tangan pakai sabun, Pengelolaan air minum dan makanan rumah tangga, Pengamanan sampah rumah tangga dan Pengamanan limbah cair rumah tangga. Sebuah studi di Indonesia menemukan bahwa kombinasi antara sanitasi yang tidak layak dan kualitas air minum yang tidak aman merupakan faktor risiko stunting (Torlesse et al., 2016). Sebuah analisis penilaian risiko komparatif global terbaru dari 137 data negara berkembang mengidentifikasi faktor-faktor risiko lingkungan (kualitas air yang buruk, kondisi sanitasi yang buruk, dan penggunaan bahan bakar padat) memiliki pengaruh terbesar kedua pada kejadian stunting secara global. Senada dengan penelitian Aisah, dkk (2019) bahwa ada hubungan antara personal hygiene dengan kejadian stunting dan ada hubungan antara sanitasi lingkungan dengan kejadian stunting. Personal hygiene dan sanitasi lingkungan yang baik merupakan faktor protektif pada kejadian stunting (Aisah, Ngaisyah and Rahmuniyati, 2019).

Kabupaten Sleman telah memiliki regulasi di sektor kesehatan lingkungan yakni Peraturan Bupati Sleman Nomor 4 Tahun 2020 tentang Sanitasi Total Berbasis Masyarakat. Melalui Perbup ini diharapkan memotivasi program STBM agar terus berkelanjutan. Karena sudah diatur peran dari masing-masing pemangku kepentingan mulai dari tingkat Kabupaten, Kapanewon, Kelurahan bahkan masyarakat. Penghargaan STBM yang telah kami terima yaitu pada tahun 2018 telah mendapatkan penghargaan STBM Berkelanjutan Kabupaten/Kota Stop BABS/ODF (Open Defecation Free) 100\%. Pada tahun 2019 mendapatkan penghargaan STBM Award kategori Sanitarian /petugas kesehatan lingkungan Puskesmas terbaik. Dan pada November tahun 2020 bertepatan dengan agenda penganugerahan STBM Award dan Rakornas STBM Ke-4 ditetapkan bahwa Kabupaten Sleman mendapatkan Penghargaan STBM Award peringkat 2 Nasional kategori Supllay Creation. tahun 2019 Pemerintah Kabupaten Sleman telah membentuk Tim Percepatan Penanggulangan Balita Stunting Kabupaten Sleman kemudian diperkuat dari Dinas Kesehatan Kabupaten Sleman pada tahun 2020 telah membuat Petunjuk Teknis Pelaksanaan Program Percepatan untuk Penanggulangan Balita di Kabupaten Sleman. Program inovasi tersebut adalah GeTAR Thala, PANdu Teman, Pecah Ranting, GAMbang Stunting, dan Tes HIV. 


\section{Inovasi Program STBM untuk Menurunkan Kasus Stunting}

Upaya penanggulangan stunting dengan inovasi program STBM yang merupakan kreasi inovasi masing - masing puskesmas. Upaya mengurangi stunting dengan beberapa inovasi dan kreativtas tersebut sangatlah diperlukan, mengingat karakteristik setiap daerah berbeda. Oleh karena program inovasi ini disesuaikan dengan budaya dan masyarakat setiap daerah. Seperti contoh :

1) Puskesmas Pakem memiliki inovasi pemeriksaan air bersih dan minum pada kantong - kantong stunting dan GAYA PUSPAKU dengan salah satu kegiatannya melakukan sosialisasi IMD, asi ekslusif, MP-ASI, sanitasi, PHBS pada pertemuan bapak-bapak. Hal ini dilakukan dengan pendekatan ayah sebagai kader stunting. Program ini berhasil dan akan menjadi contoh dan bahkan diterapkan di dusun lainnya.

2) Puskemas Tempel II melakukan pemeriksaan air bersih/minum pada kantong - kantong stunting dan membuka/memfasilitasi klinik sanitasi bagi ibu hamil serta bimbingan 1000 HPK (intervensi program gizi dan kesling). Jadi, ibu hamil yang memeriksakan diri ke Puskesmas selain mendapatkan edukasi di klinik gizi, juga mendapatkan edukasi informasi di klinik sanitasi oleh sanitarian terkait sanitasi lingkungan rumah, personal hygiene sanitasi individu maupun keluarga, pola hidup hidup bersih dan sehat. Dengan adanya inovasi ini, ibu hamil dapat selalu baik, sehat menjelang persalinan dan anaknya kelak tidak mengalami stunting.

3) Puskesmas Godean I mengadakan IPAL komunal untuk warga dan membuat komunitas pedagang cilok untuk diberikan bimbingan terkait pengelolaan/pengamanan air minum dan makanan. Adanya bimbingan pengelolaan ar minum dan makanan ini dapat meningkatkan status kesehatan, personal hygiene penjual cilok serta kebersihan makanan jajanan terjamin gizi nya dan sehat, mengingat konsumen utama makanan cilok di daerah tersebut adalah anak - anak balita dan SD. Penambahan zat gizi pada jajanan cilok juga dapat meningkatkan status gizi anak.

\section{KESIMPULAN}

Masyarakat sudah menerapkan lima pilar STBM di dalam kehidupan seharihari, implementasi program STBM ini sangat bermanfaat dapat menurunkan kasus stunting, meningkatkan hygiene personal sanitasi dan lingkungan serta perubahan perilaku untuk meningkatkan derajat kesehatan masyarakat.

\section{UCAPAN TERIMAKASIH}

Terima Kasih kepada Direktorat Riset dan Pengabdian Masyarakat Direktoral Jenderal Penguatan Riset dan Pengembangan Kementerian Riset, Teknologi, dan Pendidikan Tinggi atas hibah Penelitian Dosen Pemula yang diberikan untuk kegiatan penelitian ini. Selain itu, kepada Dinas Kabupaten Sleman yang telah memberikan izin dan dukungannya sehingga penelitian ini dapat terlaksana dengan baik, serta seluruh pihak yang terlibat dalam penelitian ini.

\section{DAFTAR PUSTAKA}

Aisah, S., Ngaisyah, D. and Rahmuniyati, M. E. (2019) 'Personal Hygiene dan Sanitasi Lingkungan dengan Kejadian Stunting di Desa Wukirsari Kecamatan Cangkringan', Prosiding Seminar Nasional Multidisiplin Ilmu, 1(2), pp. 49-55. Available at: http://prosiding.respati.ac.id/index.p hp/PSN/article/view/182/0.

Black, M. M. and Krishnakumar, A. (1999) 'Predicting longitudinal growth curves of height and weight using ecological factors for children with 
and without early growth deficiency', in Journal of Nutrition. American Institute of Nutrition, pp. 539-543. doi: 10.1093/jn/129.2.539s.

Desyanti, Chamilia; Nindya, T. S. (2017) 'Hubungan Riwayat Penyakit Diare dan Praktik Higiene dengan Kejadian Stunting pada Balita Usia 24-59 Bulan di Wilayah Kerja Puskesmas Simolawang , Surabaya The Relations Between Diarrheal Disease History and Hygiene Practices with Stunting Incidences Among', Amerta Nutrition, pp. 243-251. doi: 10.20473/amnt.v1.i3.2017.243-251.

Dinas Kesehatan Kabupaten Sleman (2018) Profil Kesehatan Kabupaten Sleman Tahun 2018. Sleman.

Dinas Kesehatan Kabupaten Sleman (2020) Profil Kesehatan Kabupaten Sleman Tahun 2020. Sleman. Available at: https://dinkes.slemankab.go.id/wpcontent/uploads/2020/09/ProfilKesehatan-Sleman-2020.pdf.

Esfarjani, F. et al. (2013) 'Determinants of stunting in school-aged children of tehran, iran.', International journal of preventive medicine. Wolters Kluwer -- Medknow Publications, 4(2), pp. 173-9. Available at: http://www.ncbi.nlm.nih.gov/pubme d/ 23543188 (Accessed: 7 December 2020).

Indriyani, Y., Yuniarti, Y. and Nur Latif, R. V. (2016) 'Kajian Strategi Promosi Kesehatan Sanitasi Total Berbasis Masyarakat (Stbm) Di Kelurahan Tirto Kecamatan Pekalongan Barat Kota Pekalongan', Unnes Journal of Public Health, 5(3), p. 240. doi: 10.15294/ujph.v5i3.11286.

Kemenkes RI (2011) Pedoman Pembinaan Perilaku Hidup Bersih dan Sehat (PHBS). Available at: https://promkes.kemkes.go.id/downl oad/jsg/files13583Pedoman_umum_ PHBS.pdf.

Kemenkes RI (2014) Permenkes Nomor 3 Tahun 2014 tentang Sanitasi Totatl Berbasis Masyarakat. Jakarta.
Available

at:https://peraturan.bkpm.go.id/jdih/ userfiles/batang/Permenkes_3_2014. pdf.

Kemenkes RI (2016) Profil Kesehatan Indonesia 2015. Jakarta.

Kemenkes RI (2017) 'Modul Pelatihan Fasilitator STBM-Stunting', in.

Kemenkes RI (2018) Riskesdas 2018. Jakarta. Available at: https://www.kemkes.go.id/resources/ download/info-terkini/hasilriskesdas-2018.pdf.

Kementerian Kesehatan Republik Indonesia (2018) Ini Penyebab Stunting pada Anak. Available at: http://www.depkes.go.id /article/view/18052800006/inipenyebab-stunting-pada-anak.html (Accessed: 16 August 2019).

Nyakaana, J. B. (1997) 'Solid Waste Management in Urban Centers: the Case of Kampala City-Uganda', East African Geographical Review, 19(1), pp. 33-43. doi: 10.1080/00707961.1997.9756235.

Proverawati, A. and Rahmawati, E. (2012) Perilaku Hidup Bersih dan Sehat (PHBS). Yogayakarta: Nuha Medika. Pusdatin (2018) Buletin Stunting 2018. Available at: http://www.p2ptm. kemkes.go.id/artikel-sehat/1-dari-3balita-indonesia-derita-

stunting\#: :text $=$ Penyebab dari stunting adalah rendahnya, lingkungan juga menjadi penyebab stunting.

Sandra, F., Syafiq, A. and Veratamala, A. (2017) Gizi Anak dan Remaja. RajaGrafindo Persada.

Sutarto, Diana Mayasari, R. I. (2018) 'Stunting, Faktor Resiko dan Pencegahannya', J Agromedicine, 5(Juni), pp. 540-545. Available at: http://repository.

lppm.unila.ac.id/9767/1/Stunting

Sutarto 2018.pdf (Accessed: 16 August 2019).

Torlesse, H. et al. (2016) 'Determinants of stunting in Indonesian children: 
Evidence from a cross-sectional survey indicate a prominent role for the water, sanitation and hygiene sector in stunting reduction', $B M C$ Public Health. BioMed Central, 16(1), p. 669. doi: 10.1186/s12889016-3339-8.

Wandansari, A. P. (2014) 'Hubungan Antara Kualitas Sumber Air Minum Dan Pemanfaatan Jamban Keluarga Dengan Kejadian Diare Di Desa Karangmangu Kecamatan Sarang Kabupaten Rembang', Unnes Journal of Public Health., 3(3), pp. 1-8. doi: 10.15294/ujph.v3i3.3537. 